\title{
SYNCHRONICZNOŚĆ WYSTĘPOWANIA ŚREDNICH ROCZNYCH STANÓW WODY JEZIOR PRZYBRZEŻNYCH I MORZA BAŁTYCKIEGO
}

\author{
ADAM PERZ, KATARZYNA PLEWA
}

\begin{abstract}
Zakład Hydrologii i Gospodarki Wodnej, Wydział Nauk Geograficznych i Geologicznych, Uniwersytet im. Adama Mickiewicza w Poznaniu, ul. B. Krygowskiego 10, 61-680 Poznań ORCID 0000-0002-2497-4390, ORCID: 0000-0001-7572-9064
\end{abstract}

\begin{abstract}
Water level fluctuations of coastal lakes are more dynamic than in case of other lakes located in the medium latitude zone. In this study, mean annual values of water level of 6 coastal lakes (Resko Przymorskie, Jamno, Bukowo, Gardno, Łebsko, Druzno) of southern coast of the Baltic Sea and sea water level were analyzed, using correlation coefficient, it was also pointed at possibility of modelling dependencies between chosen variables using Copula theory. The highest correlation coefficient was noted for the pair Łebsko Lake-Baltic Sea, gauge station in Łeba (0.91), and the lowest one for the pair Jamno Lake-Baltic Sea, gauge station in Kołobrzeg (0.67). The results of correlation analysis were proved by analysis using Archimedean Copulas. The highest synchronicity in relation to sea water levels was observed for Lebsko Lake (77.54\%), the lowest one for Jamno Lake (59.98\%). The method on the basis of Copula functions applied in the study shows that not only traditional correlation methods allow to verify dependencies and their strength between data series. There was noted strong dependency between correlation coefficient values and synchronicity. The obtained results allow to conclude that there is diversified strength of dependencies between mean annual water levels of coastal lakes in Poland and mean annual water levels of the Baltic Sea.
\end{abstract}

Keywords: water levels, coastal lakes, Baltic Sea, correlation, Copula

\section{WSTĘP}

Strefa polskiego wybrzeża charakteryzuje się obecnością procesów i zjawisk hydrologicznych niewystępujących w głębi lądu. Należą do nich m.in. cofka i intruzje wód morskich, zjawisko podparcia wiatrowego, utrudniające bądź uniemożliwiające odpływ wód z lądu do morza, oraz zjawisko piętrzenia wody, które na polskim wybrzeżu jest szczególnie widoczne podczas zimowych sztormów (Cieśliński 2010). Ze względu na swoje położenie, jeziora przybrzeżne mają inne cechy fizyczne oraz chemiczne niż pozostałe jeziora w strefie średnich szerokości geograficznych, dlatego są przedmiotem badań m.in. pod względem ich zasolenia (Cieśliński 2016), zlodzenia (Girjatowicz 2001), intruzji wód morskich (Drwal, Cieśliński 2007), bioróżnorodności (Paturej 2005, 2006). Jeziora przybrzeżne charakteryzuje odmienny niż pozostałe jeziora położone w Polsce reżim stanów wody. Obserwowane są bardziej dynamiczne ich zmiany, co jest wynikiem oddziaływania Morza Bałtyckiego 
(Chlost, Cieśliński 2005; Girjatowicz 2008a, b, 2011; Fac-Beneda 2013). Z badań reżimu stanów wody jezior w północnej Polsce wynika, że jeziora przybrzeżne stanowią odrębny typ zarówno przy podejściu nadzorowanym (Choiński 1975; Borowiak 2000), jak i nienadzorowanym (Plewa 2018). Są to jeziora o znacznych średnich rocznych amplitudach stanów wody, które przekraczają $100 \mathrm{~cm}$ (Choiński 1975) i według Borowiaka (2000) mają czterookresowy rytm zmienności sezonowej. Typ ten jest w decydującym stopniu determinowany cyrkulacją atmosferyczną oraz stanem dynamicznym Morza Bałtyckiego. W podejściu nienadzorowanym (Plewa 2018) jeziora te zostały zaliczone do odrębnej grupy. Wysokie stany wody obserwowane są w lipcu oraz od września do lutego (najwyższy współczynnik stanu wody), niskie natomiast od końca lutego do pierwszej połowy lipca, a zakres wahań stanów wody w cyklu rocznym jest niewielki. Przeprowadzono również analizę związków maksymalnych rocznych stanów wody jezior przybrzeżnych i Morza Bałtyckiego (Plewa i in. 2019). Wynika z niej, że istnieją silne zależności między stanami wody tych akwenów.

Niniejsza praca jest kontynuacją badań nad synchronicznością przebiegu zmian stanów wody jezior w zależności od wahań stanów wody morza. Jej celem jest ustalenie związków średnich rocznych stanów wody jezior przybrzeżnych położonych na polskim wybrzeżu Morza Bałtyckiego ze stanami morza z wykorzystaniem współczynnika korelacji oraz wskazanie na możliwość jednoczesnego modelowania zależności między wybranymi zmiennymi przy użyciu teorii kopul.

\section{OBSZAR BADAŃ}

Do analizy związków stanów wody jezior przybrzeżnych ze stanami morza wykorzystano średnie roczne i miesięczne wartości stanów wody z lat 19762015, które pochodzą ze zbiorów Instytutu Meteorologii i Gospodarki Wodnej PIB. Analizowano stany wody sześciu jezior przybrzeżnych: Resko Przymorskie (Dźwirzyno), Jamno (Unieście), Bukowo (Bukowo Morskie), Gardno (Gardna Wielka), Łebsko (Izbica) i Druzno (Żukowo) oraz Morza Bałtyckiego w czterech posterunkach wodowskazowych: Kołobrzeg, Ustka, Łeba i Tolkmicko. Posterunki wodowskazowe na morzu przyporządkowano jeziorom ze względu na położenie (ryc. 1). Dopasowano najbliżej położony posterunek z odpowiednio długim ciągiem danych.

Jeziora Resko Przymorskie, Jamno, Bukowo, Gardno i Łebsko są połączone z morzem kanałami będącymi ujściowymi odcinkami rzek do morza. Jezioro Jamno jest połączone z morzem Kanałem Jamneńskim, Bukowo - Kanałem Szczuczym, Gardno - Kanałem Łupawy, Łebsko - Kanałem Łeby (Girjatowicz 2008a), a jezioro Resko Przymorskie - Kanałem Błotnicy (Burandt i in. 2017). 


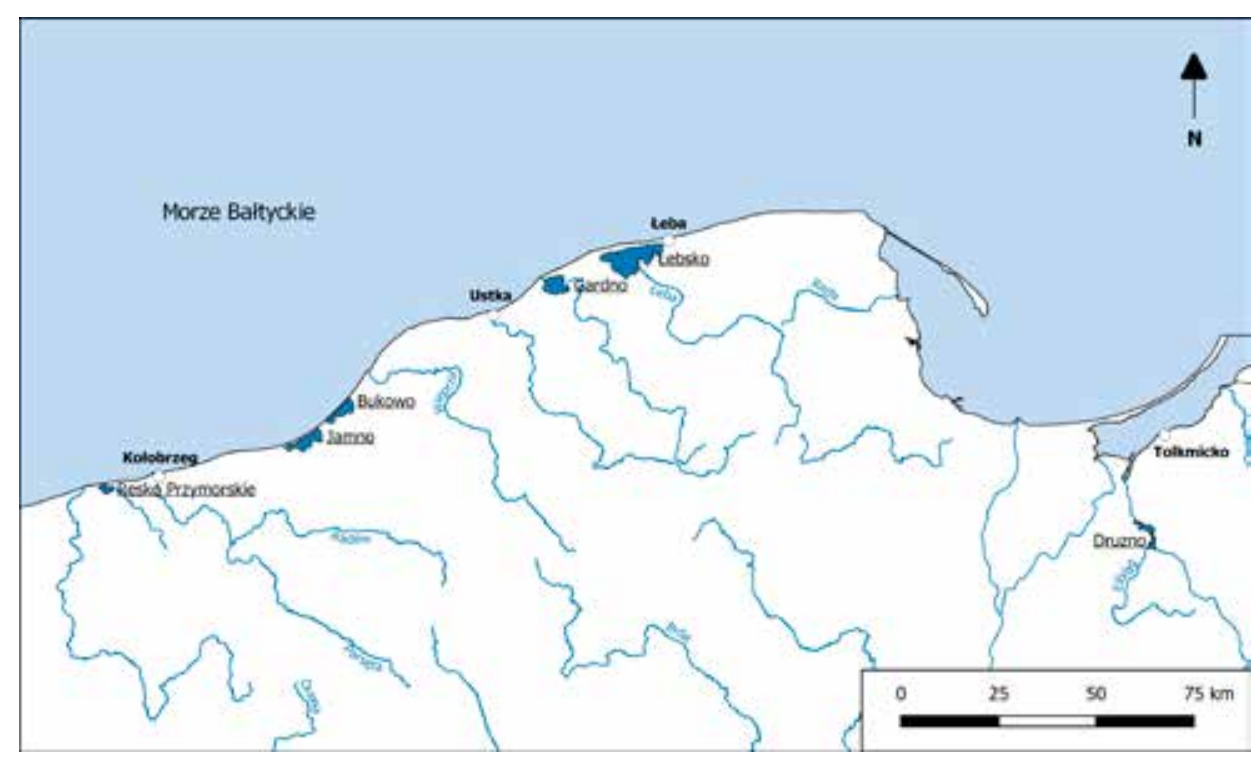

Ryc. 1. Położenie obiektów badań

Fig. 1. Location of objects of research

Jezioro Druzno, położone na wschodzie badanego obszaru, jest połączone z Morzem Bałtyckim przez Zalew Wiślany.

Badane jeziora mają różną powierzchnię. Najmniejsze jest jezioro Resko Przymorskie $-5,59 \mathrm{~km}^{2}$, natomiast największe Łebsko o powierzchni ponad 70 $\mathrm{km}^{2}$ (tab. 1). Są to jeziora stosunkowo płytkie, o średniej głębokości od 1,2 m (Druzno) do 1,8 m (Bukowo) oraz głębokości maksymalnej od 2,5 m (Resko Przymorskie i Druzno) do 6,3 m (Łebsko).

\section{METODY BADAŃ}

W analizie wykorzystano wiele metod statystycznych, na podstawie których zbadano tendencje wahań średnich rocznych i miesięcznych stanów wody morza i jezior oraz związki stanów wody jezior ze stanami wody morza (na podstawie analizy korelacyjnej oraz analizy synchroniczności). Metody te szczegółowo opisano poniżej.

\section{Test Manna-Kendalla}

W pierwszym etapie przeprowadzonej analizy zbadano tendencje wahań średnich rocznych i miesięcznych stanów wody zarówno jezior, jak i morza 
Tabela 1. Parametry morfometryczne i hydrologiczne badanych jezior

Table 1. Morphometric and hydrologic parameters of analyzed lakes

\begin{tabular}{lccccccc}
\hline \multicolumn{1}{c}{ Jezioro } & $\begin{array}{c}\text { Powierzchnia } \\
\text { zlewni }\left[\mathrm{km}^{2}\right]^{*}\end{array}$ & $\begin{array}{c}\text { Powierzchnia } \\
\text { jeziora }\left[\mathrm{km}^{2}\right]^{* *}\end{array}$ & $\begin{array}{c}\text { Objętość } \\
{\left[\mathrm{tys} . \mathrm{m}^{3}\right]^{* *}}\end{array}$ & $\begin{array}{c}\text { Głębokość } \\
\text { średnia } \\
{[\mathrm{m}]^{* *}}\end{array}$ & $\begin{array}{c}\text { Głębokość } \\
\text { maksymalna } \\
{[\mathrm{m}]^{* *}}\end{array}$ & $\begin{array}{c}\text { Indeks } \\
\text { Schindlera } \\
\left(\mathrm{m}^{-1}\right)\end{array}$ & $\begin{array}{c}\text { Indeks } \\
\text { Ohlego } \\
{[-]}\end{array}$ \\
\hline $\begin{array}{l}\text { Resko } \\
\text { Przymorskie }\end{array}$ & 316,97 & 5,59 & 7703,4 & 1,3 & 2,5 & 41,147 & 56,703 \\
Jamno & 483,54 & 22,315 & 31528 & 1,4 & 3,9 & 15,337 & 21,669 \\
Bukowo & 85,76 & 16,44 & 32071,7 & 1,8 & 2,8 & 2,674 & 5,217 \\
Gardno & 928,84 & 23,375 & 30950,5 & 1,3 & 2,6 & 30,011 & 39,737 \\
Łebsko & 1563,01 & 70,2 & 117521 & 1,6 & 6,3 & 13,300 & 22,265 \\
Druzno & 1061,3 & 11,475 & 17352 & 1,2 & 2,5 & 61,163 & 92,488 \\
\hline
\end{tabular}

Źródło: * Czarnecka (2005), ** Choiński (2006).

w poszczególnych posterunkach. Dokonano tego za pomocą nieparametrycznego testu Manna-Kendalla, służącego do wykrywania trendu w szeregach czasowych. Obliczenia wykonano przy użyciu nakładki MAKESENS w programie Microsoft Excel, przygotowanej przez naukowców z Finnish Meteorological Institute (Salmi et al. 2012). Test Manna-Kendalla można zastosować, gdy wartości danych $x_{\mathrm{i}}$ dla wielolecia można przypisać do wzoru:

$$
x_{i}=f(t)+\varepsilon_{i}
$$

gdzie $f(t)$ jest ciągłą malejącą lub rosnącą funkcją czasu, a pozostałości $\varepsilon_{i}$ mogą być traktowane jako pochodzące $\mathrm{z}$ tego samego rozkładu o średniej równej 0 . Przez to odchylenie od rozkładu może być uznane jako niezmienne w czasie. W związku z powyższym statystyka $S$ testu Manna-Kendalla może zostać obliczona na podstawie wzoru:

$$
S=\sum_{k=1}^{n-1} \sum_{j=k+1}^{n} \operatorname{sgn}\left(x_{j}-x_{k}\right)
$$

gdzie $x_{j}$ i $x_{k}$ są zbiorami danych maksymalnych stanów wody dobowych rocznych ułożonych w postaci szeregów czasowych w odpowiadających im momentach czasowych $j$ i $k$, przy $j>k$ :

$$
\operatorname{sgn}\left(x_{j}-x_{k}\right)=\left\{\begin{array}{c}
1 \text { dla } x_{j}-x_{k}>0 \\
0 \text { dla } x_{j}-x_{k}=0 \\
-1 \text { dla } x_{j}-x_{k}<0
\end{array}\right.
$$


Malejące lub rosnące trendy określa się na podstawie ujemnej lub dodatniej wartości $Z$. Aby ją obliczyć, w pierwszej kolejności należy obliczyć $V A R(S)$ ze wzoru:

$$
\operatorname{VAR}(S)=\frac{1}{18}\left[n(n-1)(2 n+5)-\sum_{p=1}^{q} t_{p}\left(t_{p}-1\right)\left(2 t_{p}+5\right)\right]
$$

gdzie $q$ to numer wartości stanu wody, a $t_{p}$ to liczba wartości w $p$-tej grupie. $\mathrm{Na}$ podstawie wartości $S$ i $\operatorname{VAR}(S)$ obliczono wartość $Z$ według wzoru:

$$
Z= \begin{cases}\frac{S-1}{\sqrt{V A R(S)}} & \text { jeśli } S>0 \\ 0 & \text { jeśli } S=0 \\ \frac{S+1}{\sqrt{V A R(S)}} & \text { jeśli } S<0\end{cases}
$$

Powyższa procedura umożliwia sprawdzenie hipotezy zerowej $H_{0}$ o braku trendów. Obserwacje $x_{i}$ są ułożone chronologicznie, a hipoteza $H_{1}$ określa malejący lub rosnący monotonicznie trend. Test $Z$ ma rozkład normalny, a co się z tym wiąże - wartość bezwzględna $Z$ może być porównana ze zsumowanym rozkładem normalnym, aby ustalić, czy istnieje monotoniczny trend, a jeśli tak, to o jakim poziomie istotności statystycznej. W rezultacie przeprowadzenia powyższych obliczeń stwierdzono trendy pozytywne bądź negatywne. Trendy charakteryzujące się istotnością statystyczną określone zostały w trzystopniowej skali.

\section{Korelacja rang Spearmana}

Za pomocą metody korelacji rang Spearmana oraz regresji liniowej zbadano związki stanów wody jezior ze stanami wody morza. Statystycznej oceny istotności współczynników korelacji dokonano za pomocą statystyki $t$ :

$$
t=\frac{r \sqrt{n-2}}{\sqrt{1-r^{2}}}
$$

Statystyka $t$ ma rozkład Studenta z $n-2$ stopniami swobody. 


\section{Ocena synchroniczności w oparciu o funkcje kopul}

Procedurę wyboru najlepiej dopasowanych rozkładów dla analizowanych ciągów danych oparto na metodzie największego prawdopodobieństwa (Zhao i in. 2012). Do badania użyto rozkładów Weibulla, Gamma, Gumbela i log-normalnego. W celu oceny dopasowania rozkładu do ciągu danych wykorzystano Akaike Information Criterion (AIC) (Akaike 1974), które obliczono ze wzoru:

$\mathrm{AIC}=N \log (\mathrm{MSE})+2($ liczba dopasowanych parametrów $)$

gdzie MSE to średni błąd kwadratowy (mean square error), $N$ to liczebność próby.

Najlepiej dopasowanym rozkładem bądź modelem jest ten, dla którego AIC przyjmuje najniższą wartość.

Następnym krokiem było skonstruowanie rozkładu łącznego stanów jezior i morza na podstawie funkcji kopul. Koncepcja funkcji kopuli została przedstawiona przez Sklara (1959), który zdefiniował kopulę jako funkcję łącznego rozkładu zmiennych. Funkcje te są coraz częściej wykorzystywane w analizach danych hydrometeorologicznych. W przeciwieństwie do wielu innych metod nie ograniczają ich różne rozkłady statystyczne analizowanych ciągów danych.

Dwuwymiarowe kopule archimedejskie mogą być zdefiniowane ogólnie jako (Nelsen 1999):

$$
C_{\theta}(u, v)=\phi^{-1}\{\phi(u)+\phi(v)\}
$$

gdzie $\theta$ kopuli $C$ jest parametrem generującej funkcji $\varphi, \varphi$ jest funkcją ciągłą, zwaną generatorem, malejącą i przybierającą wartości w zakresie od $I=[0,1]$ do $[0, \varphi(0)]$.

W niniejszej pracy wykorzystano kopule archimedejskie z rodzin: Claytona, Gumbela-Hougaarda oraz Franka (tab. 2).

Tabela 2. Rodziny kopul, ich generatory i parametry oraz związek $\tau_{\theta}$ Kendalla z parametrem kopuli Table 2. Copula famielies, their generators and relationship of Kendall's $\tau_{\theta}$ with a copula parameter

\begin{tabular}{lcccc}
\hline $\begin{array}{c}\text { Rodzina } \\
\text { kopul }\end{array}$ & $C_{\theta}(u, v)$ & $\begin{array}{c}\text { Generator } \\
\phi(t)\end{array}$ & $\begin{array}{c}\text { Parametr } \\
\theta \in\end{array}$ & $\begin{array}{c}\tau_{\theta} \\
\text { Kendalla }\end{array}$ \\
\hline Clayton & $\max \left(\left(u^{-\theta}+v^{-\theta}-1\right)^{-1 / \theta}, 0\right)$ & $\frac{1}{\theta}\left(t^{-\theta}-1\right)$ & {$[-1, \infty) \backslash\{0\}$} & $\tau=\theta /(2+\theta)$ \\
Gumbel- & $\exp \left\{-\left[(-\ln u)^{\theta}+(-\ln v)^{\theta}\right]^{1 / \theta}\right\}$ & $(-\ln t)^{\theta}$ & {$[1, \infty)$} & $(\theta-1) / \theta$ \\
Hougaard & & & \\
Frank & $\frac{-1}{\theta} \ln \left[1+\frac{\left(e^{-\theta_{u}}-1\right)\left(e^{-\theta_{v}}-1\right)}{e^{-\theta}-1}\right]$ & $-\ln \frac{e^{-\theta t}-1}{e^{-\theta}-1}$ & $(-\infty, \infty) \backslash\{0\}$ & $1+4\left[D_{1}(\theta)-1 \bigvee \theta\right.$ \\
\hline
\end{tabular}

$D_{k}(x)$ jest funkcją Debye'a, dla każdego dodatniego $k, D_{k}(x)=\frac{k}{k^{x}} \int_{0}^{x} \frac{t^{k}}{e^{t}-1} d t$. 
Najlepiej dopasowanym rozkładem łącznym jest ten, dla którego AIC przyjmuje najniższą wartość.

Dla każdej porównywanej pary ciągów, na podstawie obliczonych parametrów rozkładu statystycznego, wygenerowano 5 tys. hipotetycznych punktów, które posłużyły do wybrania najlepiej dopasowanej rodziny kopul, a następnie do skonstruowania odpowiedniej kopuli. Opierając się na empirycznych parach wartości dla poszczególnych lat i wygenerowanych punktach hipotetycznych, stworzono wykresy z krzywymi prawdopodobieństwa (wyrażonym okresami powtarzalności) - rycina 2 .

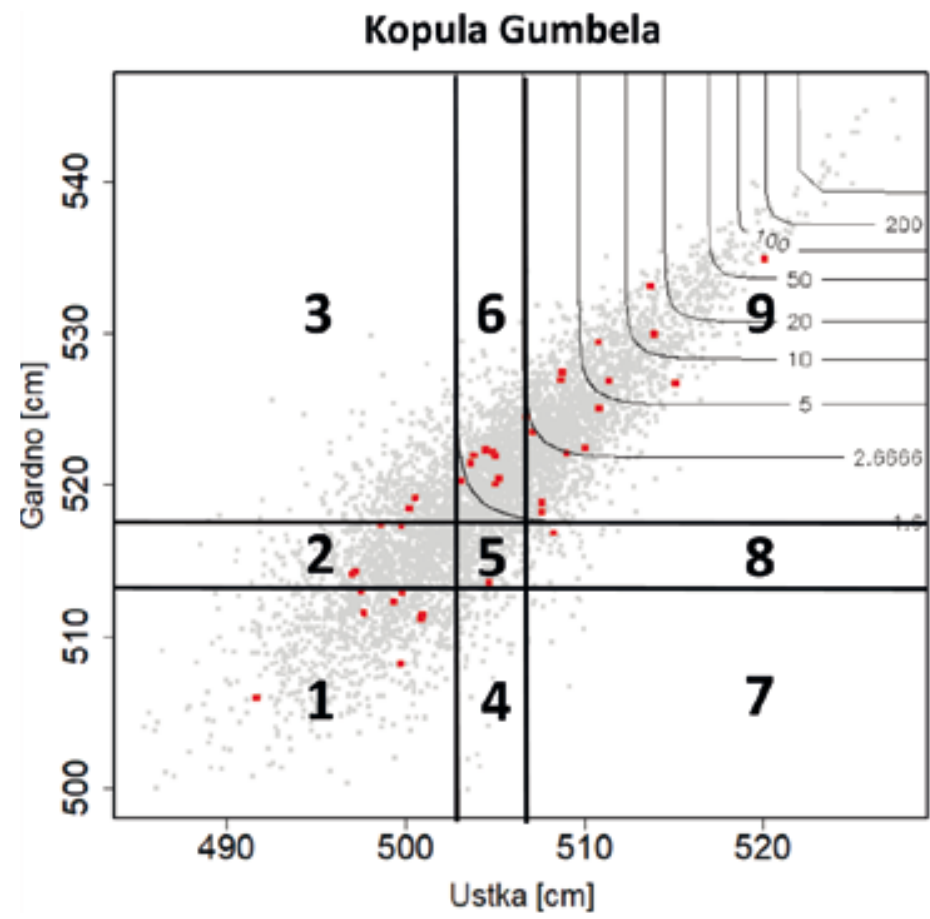

Ryc. 2. Przykład łącznych skumulowanych krzywych prawdopodobieństwa przekroczeń stanów średnich i wyznaczenia sektorów o różnym stopniu synchroniczności lub asynchroniczności występowania średnich stanów

Fig. 2. Example of combined accumulated curves of the probability of exceedance of mean annual water levels and the determination of sectors with various degrees of synchronicity or asynchronicity of mean annual water levels

Następnie oceniono stopień synchroniczność i asynchroniczności występowania średnich stanów jezior i morza. Dla każdej pary posterunków przedstawiono krzywe prawdopodobieństwa na poziomie:

- $62,5 \%$ (raz na 1,6 roku),

- $37,5 \%$ (raz na ok. 2,7 roku), 
- $20 \%$ (raz na 5 lat),

- $10 \%$ (raz na 10 lat),

- $2 \%$ (raz na 50 lat),

- $1 \%$ (raz na 100 lat),

- $0,5 \%$ (raz na 200 lat),

- $0,2 \%$ (raz na 500 lat).

Analizę otrzymanych danych oparto na prawdopodobieństwie $62,5 \%$ i 37,5\% (Zhang i in. 2014). Ustalono dziewięć sektorów obrazujących różne relacje między prawdopodobnymi stanami wody (ryc. 2). Na podstawie wygenerowanych punktów o rozkładzie naśladującym wspólny rozkład wartości z porównywanych posterunków wodowskazowych i ich udziału w poszczególnych sektorach (ryc. 2) wyróżniono trzy sektory o synchronicznych wystąpieniach stanów średnich:

- $\quad$ sektor $1-\mathrm{NSH}_{M}-\mathrm{NSH}_{J}\left(X \leq M_{62,5 \%}, Y \leq J_{62,5 \%}\right)$

- sektor $5-\mathrm{SSH}_{M}-\mathrm{SSH}_{J}\left(M_{62,5 \%}<X \leq M_{37,5 \%}, J_{62,5 \%}<Y \leq J_{37,5 \%}\right)$

- sektor $9-\mathrm{WSH}_{M}-\mathrm{WSH}_{J}\left(X>M_{37,5 \%}, Y>J_{37,5 \%}\right)$

oraz sześć sektorów o wystąpieniach asynchronicznych:

- sektor $2-\mathrm{NSH}_{M}-\mathrm{SSH}_{J}\left(X \leq M_{62,5 \%}, J_{62,5 \%}<Y \leq J_{37,5 \%}\right)$

- sektor $3-\mathrm{NSH}_{M}-\mathrm{WSH}_{J}\left(X \leq M_{62,5 \%}, Y>J_{37,5 \%}\right)$

- sektor $4-\mathrm{SSH}_{M}-\mathrm{NSH}_{J}\left(M_{62,5 \%}<X \leq M_{37,5 \%}, Y \leq J_{62,5 \%}\right)$

- sektor $6-\mathrm{SSH}_{M}-\mathrm{WSH}_{J}\left(M_{62,5 \%}<X \leq M_{37,5 \%}, Y>J_{37,5 \%}\right)$

- $\quad$ sektor $7-\mathrm{WSH}_{M}-\mathrm{NSH}_{J}\left(X>M_{37,5 \%}, Y \leq J_{62,5 \%}\right)$

- sektor $8-\mathrm{WSH}_{M}-\mathrm{SSH}_{J}\left(X>M_{37,5 \%}, J_{62,5 \%}<Y \leq J_{37,5 \%}\right)$

gdzie:

$X$ - wartości odciętych wygenerowanych punktów

$Y$ - wartości rzędnych wygenerowanych punktów

$M_{62,5 \%}$ - wartość średniego stanu morza o prawdopodobieństwie przewyższenia $62,5 \%$

$M_{37,5 \%}$ - wartość średniego stanu morza o prawdopodobieństwie przewyższenia $37,5 \%$

$J_{62,5 \%}$ - wartość średniego stanu jeziora o prawdopodobieństwie przewyższenia $62,5 \%$

$J_{37,5 \%}$ - wartość średniego stanu jeziora o prawdopodobieństwie przewyższenia $37,5 \%$.

Procentowy udział punktów zawartych w sektorach 1, 5 i 9 określa stopień synchroniczności stanów średnich rocznych między dwoma badanymi akwenami w danej jednostce czasu.

Synchroniczność i asynchroniczność występowania stanów średnich zostały określone w wyniku ustalenia wartości granicznych przedziałów prawdopodobieństwa:

- stany średnie prawdopodobne o prawdopodobieństwie wystąpienia $<62,5 \%$ określono jako NSH, 
- stany średnie prawdopodobne o prawdopodobieństwie wystąpienia $\mathrm{w}$ przedziale $>62,5 \% \mathrm{i}<37,5 \%$ określono jako $\mathrm{SSH}$,

- stany średnie prawdopodobne o prawdopodobieństwie wystąpienia $>37,5 \%$ określono jako WSH.

I tak przykładowo wystąpienie NSH danego jeziora jest zdarzeniem synchronicznym, jeśli na Bałtyku w danej jednostce czasu również wystąpi NSH, natomiast asynchronicznym, jeśli odnotowany zostanie tam SSH lub WSH. Suma synchroniczności i asynchroniczności zawsze równa się 100\%.

W matematyczno-statystycznym opracowaniu wyników analiz wykorzystano procedury statystyczne zawarte w programach: Excel (Microsoft), Statistica (StatSoft) oraz RStudio. Do realizacji zaś strony graficznej użyto programów Quantum GIS (3.6.2. Noosa) oraz Publisher (Microsoft).

\section{WYNIKI I DYSKUSJA}

Analizowane jeziora charakteryzują się wysokimi wartościami średnich rocznych amplitud stanów wody. We wszystkich jeziorach wynoszą one ponad $100 \mathrm{~cm}$; najwyższe w przypadku jeziora Resko Przymorskie $(111 \mathrm{~cm})$, najniższe dla jeziora Jamno $(73 \mathrm{~cm})$ - tabela 3. Dobowy współczynnik zmienności stanów wody waha się od 0,036 w Łebsku do 0,044 w jeziorze Bukowo, a we wszystkich posterunkach zlokalizowanych na Morzu Bałtyckim wynosi 0,041 - tabela 3.

Tabela 3. Charakterystyki zmienności stanów wody analizowanych akwenów

Table 3. Characteristics of water level variability of analyzed water bodies

\begin{tabular}{lcc}
\hline \multicolumn{1}{c}{ Jezioro/Posterunek } & $\begin{array}{c}\text { Średnia roczna amplituda } \\
\text { stanów wody }\end{array}$ & $\begin{array}{c}\text { Dobowy współczynnik } \\
\text { zmienności } C v\end{array}$ \\
\hline Jeziora & 111 & 0,043 \\
Resko Przymorskie & 73 & 0,040 \\
Jamno & 82 & 0,044 \\
Bukowo & 88 & 0,040 \\
Gardno & 86 & 0,036 \\
Łebsko & 97 & 0,041 \\
Druzno & & 0,041 \\
Morze Bałtyckie & 132 & 0,041 \\
Kołobrzeg & 119 & 0,041 \\
Ustka & 114 & 0,041 \\
Łeba & 124 & \\
Tolkmicko & &
\end{tabular}


Test Manna-Kendalla dla średnich rocznych stanów wody jezior wykazał tendencję rosnącą, przy czym stany wody jezior Druzno i Jamno mają trendy istotne statystycznie na poziomie istotności $p<0,001$, a stany wody jeziora $\mathrm{Bu}-$ kowo na poziomie istotności $p<0,01$ (tab. 4). W przypadku średnich miesięcznych stanów wody jezior Bukowo, Druzno i Jamno przez cały rok obserwuje się trendy rosnące. Stany wody jeziora Jamno wykazują trendy istotne statystycznie przez cały rok, z kolei stany jeziora Bukowo od lutego do lipca, a jeziora Druzno w listopadzie oraz od lutego do sierpnia. Stany wody jeziora Resko Przymorskie od grudnia do października mają trendy rosnące, istotne statystycznie jedynie w czerwcu. W przypadku jeziora Gardno obserwuje się trendy rosnące od lutego do czerwca, istotne statystycznie na poziomie $p<0,01 \mathrm{w}$ czerwcu. $\mathrm{W}$ pozostałych miesiącach tendencje wahań stanów wody są ujemne, nieistotne statystycznie.

Analizując tendencje wahań średnich rocznych stanów wody Morza Bałtyckiego, zauważa się, że we wszystkich profilach trendy wahań stanów wody są dodanie. W Kołobrzegu w latach 1976-2015 oraz w Tolkmicku istotne statystycznie na poziomie $p<0,01$, a w Ustce na poziomie $p<0,05$. Trendy miesięcznych stanów wody w Kołobrzegu w wieloleciu 1976-2015 oraz w Tolkmicku we wszystkich miesiącach są dodatnie, istotne statystycznie od marca do czerwca w Kołobrzegu, a w Tolkmicku od marca do czerwca i w sierpniu. $\mathrm{Na}$ pozostałych stacjach w grudniu, styczniu oraz we wrześniu i październiku obserwuje się trendy malejące.

W pracy obliczono współczynniki korelacji oraz określono stopień synchroniczności występowania średnich rocznych stanów wody analizowanych jezior przybrzeżnych w porównaniu ze stanami wody Morza Bałtyckiego. Najwyższy współczynnik korelacji zanotowano dla pary jezioro Łebsko-Morze Bałtyckie, posterunek w Łebie $(0,91)$, natomiast najniższy dla pary jezioro Jamno-Morze Bałtyckie, posterunek w Kołobrzegu $(0,67)$ - tabela 5. Wysoki współczynnik korelacji $(>0,8)$ odnotowano również dla par: jezioro Gardno-Morze Bałtyckie, posterunek w Ustce oraz jezioro Resko Przymorskie i Morze Bałtyckie, posterunek w Kołobrzegu. Generalnie w przypadku wszystkich badanych par jezioromorze korelacje są istotne statystycznie na poziomie $p<0,001$.

Wyniki analizy za pomocą regresji liniowej również wskazują na wysoką zależność między wahaniami stanów wody jezior przybrzeżnych a wahaniami stanów morza. Najwyższy współczynnik determinacji $R^{2}$ zanotowano dla pary jezioro Łebsko-Morze Bałtyckie, posterunek w Łebie $(0,88)$, natomiast najniższy dla pary Resko Przymorskie-Kołobrzeg (ryc. 3). Związki stanów wody jezior i morza we wszystkich analizowanych przypadkach są istotne statystycznie na poziomie $p<0,001$.

Analizę wykonano również wykorzystując kopule archimedejskie, które posłużyły do obliczenia synchroniczności i asynchroniczności występowania średnich stanów jezior przybrzeżnych i Bałtyku. Modelowanie zależności 


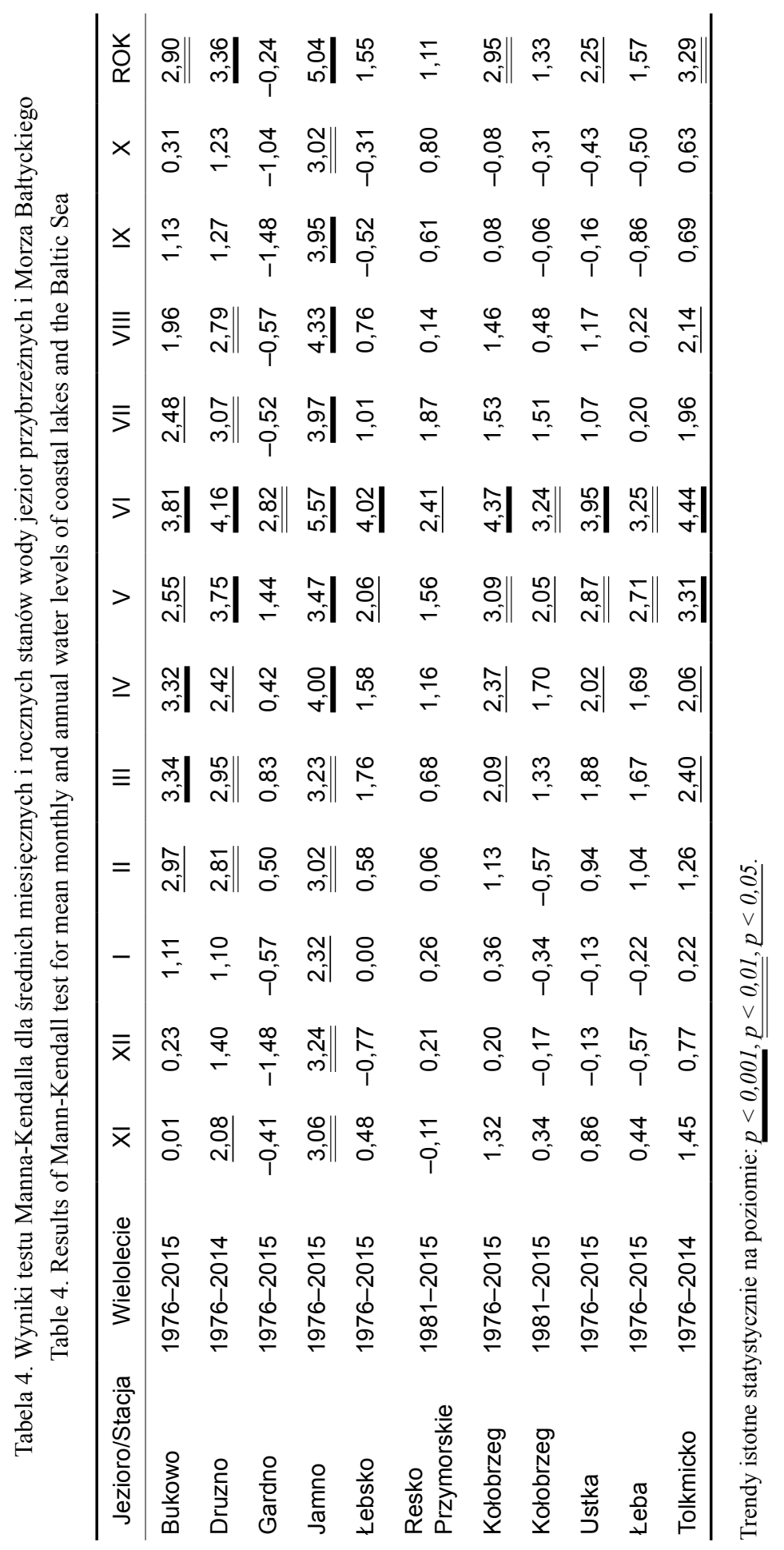


Tabela 5. Wyniki analizy korelacyjnej i synchroniczności między wahaniami średnich rocznych stanów wody jezior przybrzeżnych i Morza Bałtyckiego

Table 5. Results of correlation analysis and synchronicity between fluctuations of mean annual water levels of coastal lakes and the Baltic Sea

\begin{tabular}{|c|c|c|c|c|c|}
\hline \multirow[b]{2}{*}{ Lp. } & \multirow{2}{*}{$\begin{array}{c}\text { Posterunki } \\
\text { wodowskazowe } \\
\text { (morze-jezioro) }\end{array}$} & \multirow[b]{2}{*}{ Okres } & \multicolumn{3}{|c|}{ Stany średnie roczne } \\
\hline & & & $\begin{array}{c}\text { synchroniczność } \\
{[\%]}\end{array}$ & $\begin{array}{c}\text { asynchroniczność } \\
{[\%]}\end{array}$ & $\begin{array}{l}\text { korelacja } \\
p<0,001\end{array}$ \\
\hline 1 & $\begin{array}{l}\text { Kołobrzeg-Resko } \\
\text { Przymorskie }\end{array}$ & $1981-2015$ & 69,34 & 30,66 & 0,81 \\
\hline 2 & Kołobrzeg-Jamno & $1976-2015$ & 59,98 & 40,02 & 0,67 \\
\hline 3 & Ustka-Bukowo & $1976-2015$ & 67,48 & 32,52 & 0,76 \\
\hline 4 & Ustka-Gardno & $1976-2015$ & 70,72 & 29,28 & 0,84 \\
\hline 5 & Łeba-Łebsko & $1976-2015$ & 77,54 & 22,46 & 0,91 \\
\hline 6 & Tolkmicko-Druzno & $1976-2014$ & 66,28 & 33,72 & 0,75 \\
\hline
\end{tabular}

za pomocą funkcji kopuli umożliwia ustalenie siły zależności między stanami wody porównywanych akwenów. Dodatkową zaletą kopuli jest możliwość wymiernego określenia prawdopodobieństwa występowania każdej analizowanej zmiennej oddzielnie oraz prawdopodobieństwa współwystępowania stanów średnich rocznych jezior i morza oraz stopnia ich synchroniczności.

Najwyższą synchroniczność zaobserwowano dla pary jezioro Łebsko-Łeba (77,54\%), najniższą dla pary jezioro Jamno-Kołobrzeg (59,98\%) (tab. 5, 6). Stosunkowo wysoką synchronicznością (> 70\%) średnich stanów rocznych charakteryzuje się para jezioro Gardno-Ustka, a niewiele niższą para jezioro Resko Przymorskie-Kołobrzeg. Oznacza to przykładowo, że z prawdopodobieństwem 77,54\% (czyli statystycznie trochę częściej niż raz na cztery lata) stany średnie roczne Łebska i Bałtyku będą zgodne, czyli znajdą się w tym samym przedziale prawdopodobieństwa (będzie to zdarzenie synchroniczne, czyli należące do jednego z trzech sektorów: $\mathrm{NSH}_{M}-\mathrm{NSH}_{J}, \mathrm{SSH}_{M}-\mathrm{SSH}_{J}, \mathrm{WSH}_{M}-\mathrm{WSH}_{J}$. Uzyskane wyniki synchroniczności są zgodne z wynikami korelacji (tab. 5).

Wyniki można interpretować także na bardziej szczegółowym poziomie poszczególnych sektorów. Przykładowo w połowie analizowanych jezior (Resko, Bukowo i Druzno) bardziej prawdopodobne jest wystąpienie synchronicznej sytuacji w przypadku niskich stanów $\left(\mathrm{NSH}_{M}-\mathrm{NSH}_{J}\right.$, sektor 1$)$ niż wysokich stanów $\left(\mathrm{WSH}_{M}-\mathrm{WSH}_{J}\right.$, sektor 9) średnich rocznych.

W porównaniu z analizą związków maksymalnych rocznych stanów wody jezior przybrzeżnych i Morza Bałtyckiego generalnie wyższą synchroniczność wykazują średnie roczne stany wody jezior i morza. Wyjątek stanowi jezioro Resko Przymorskie, którego stopień synchroniczności maksymalnych rocznych stanów wody wynosi 75\% (Plewa i in. 2019), a średnich rocznych stanów wody 69\%. 

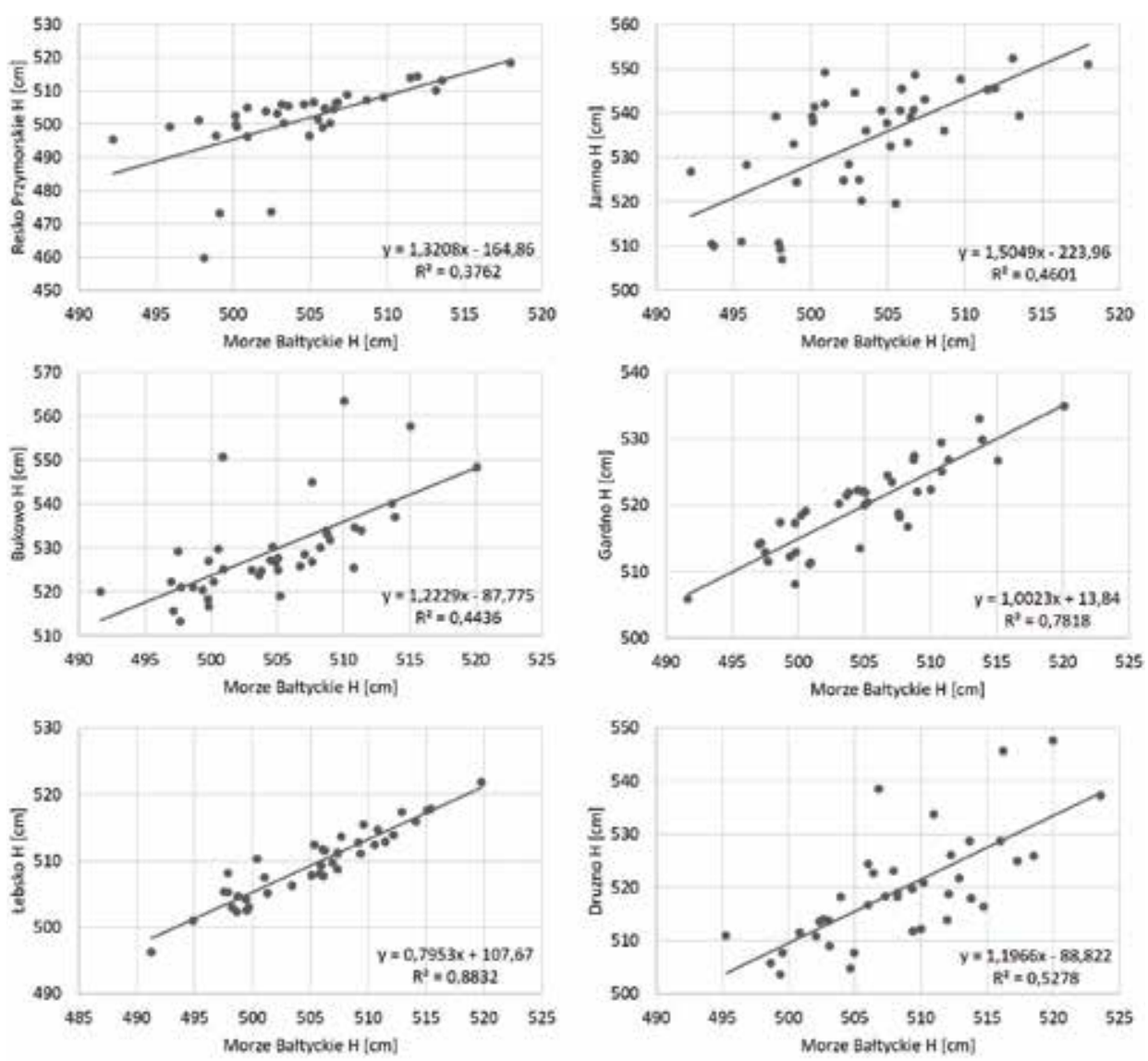

Ryc. 3. Korelacje średnich rocznych stanów wody analizowanych jezior i Morza Bałtyckiego

Fig. 3. Correlations of mean annual water levels of analyzed lakes and the Baltic Sea

Synchroniczność można także oszacować na podstawie graficznego przedstawienia wygenerowanych punktów, opartego na obliczonych parametrach rozkładu łącznego - im bardziej punkty są skoncentrowane w osi wykresu, tym synchroniczność jest wyższa (ryc. 4).

Dodatkowo sprawdzono korelacje średnich miesięcznych stanów wody jezior przybrzeżnych i Morza Bałtyckiego. Związki miesięcznych stanów wody jezior przybrzeżnych i morza są silne i właściwie przez cały rok istotne statystycznie na poziomie istotności $p<0,001$. Najwyższe miesięczne współczynniki korelacji obserwuje się w jeziorach Gardno i Łebsko, natomiast najniższe w jeziorach Jamno i Bukowo. Jak twierdzi Girjatowicz (2011), może to być związane z drożnością przetok oraz ilością wody odpływającej do morza. Przeciętny odpływ wody z jezior Jamno i Bukowo wynosi do kilku metrów sześciennych na sekundę, a z jezior Gardno i Łebsko odpowiednio: 8-12 $\mathrm{m}^{3} \times \mathrm{s}^{-1} 12-17 \mathrm{~m}^{3} \times \mathrm{s}^{-1}$ 
Tabela 6. Wyniki synchroniczności stanów wody analizowanych jezior i Morza Bałtyckiego w podziale na sektory [\%]

Table 6. Results of synchronicity of water levels of analyzed lakes and the Baltic Sea by sectors [\%]

\begin{tabular}{lcrrrrr}
\hline Sektor & $\begin{array}{c}\text { Kołobrzeg- } \\
\text { Resko }\end{array}$ & $\begin{array}{c}\text { Kołobrzeg- } \\
\text { Jamno }\end{array}$ & $\begin{array}{c}\text { Ustka- } \\
\text { Bukowo }\end{array}$ & $\begin{array}{c}\text { Ustka- } \\
\text { Gardno }\end{array}$ & $\begin{array}{r}\text { Łeba- } \\
\text { Łebsko }\end{array}$ & $\begin{array}{c}\text { Tolkmicko- } \\
\text { Druzno }\end{array}$ \\
\hline 1 & 29,06 & 24,52 & 29,10 & 27,9 & 31,14 & 27,94 \\
5 & 11,52 & 8,98 & 10,68 & 12,36 & 14,00 & 10,54 \\
9 & 28,76 & 26,48 & 27,70 & 30,46 & 32,40 & 27,80 \\
2 & 7,52 & 8,58 & 7,24 & 7,36 & 5,58 & 7,28 \\
4 & 7,42 & 8,98 & 7,38 & 7,52 & 5,66 & 7,22 \\
8 & 6,18 & 7,26 & 7,18 & 5,54 & 5,16 & 7,64 \\
6 & 6,18 & 7,62 & 7,02 & 6,02 & 4,92 & 7,18 \\
9 & 1,62 & 3,62 & 1,70 & 1,46 & 0,58 & 2,18 \\
7 & 1,74 & 3,96 & 2,00 & 1,38 & 0,56 & 2,22 \\
Syn. & 69,34 & 59,98 & 67,48 & 70,72 & 77,54 & 66,28 \\
Asyn. & 30,66 & 40,02 & 32,52 & 29,28 & 22,46 & 33,72 \\
\hline
\end{tabular}

(Girjatowicz 2011). Przepływ wód między jeziorami Gardno i Łebsko a morzem jest prawie niezakłócony, co sprzyja stosunkowo szybkiemu wyrównywaniu się poziomu wód między tymi akwenami. W Kanale Łupawy, stanowiącym połączenie jeziora Gardno z morzem, okresowo dochodzi do zapiaszczania pewnej części przekroju poprzecznego koryta w odcinku ujściowym. Może to utrudniać wymianę wody, lecz w ujściu kanału położony jest port rybacki - Rowy, gdzie prowadzi się prace pogłębiarskie. Podobnie jest w przypadku portu Łeba, położonego w ujściu Kanału Łeby. Również w odcinku ujściowym Kanału Resko (Błotnicy) jest zlokalizowany port morski w miejscowości Dźwirzyno, dlatego może to thumaczyć wysokie korelacje stanów wody jeziora Resko Przymorskie ze stanami wody morza. Najsłabiej skorelowane ze stanami wody morza są stany wody jezior Jamno i Bukowo. Jak twierdzi Girjatowicz (2008a), wiąże się to $\mathrm{z}$ utrudnioną wymianą wód $\mathrm{z}$ morzem, spowodowaną zatarasowywaniem przez wały piaszczyste i wały śryżowe ujściowych odcinków kanałów do morza. Wówczas na skutek zablokowania odpływu występuje stosunkowo wysoki poziom wody $\mathrm{w}$ jeziorach $\mathrm{w}$ porównaniu $\mathrm{z}$ poziomem wody w morzu. Zauważa się również, że w przypadku większości badanych jezior wyższe korelacje obserwowane są w chłodnej porze roku. Generalnie może być to związane z zasilaniem jezior w okresie jesienno-zimowym wodami morskimi, które wskutek sztormów przedostają się do jezior przez przetoki (Cyberski, Jędrasik 1992; Girjatowicz 2011).

Podobne wyniki analizy korelacyjnej uzyskano dla maksymalnych miesięcznych stanów wody jezior i morza. Współczynniki korelacji między maksymal- 

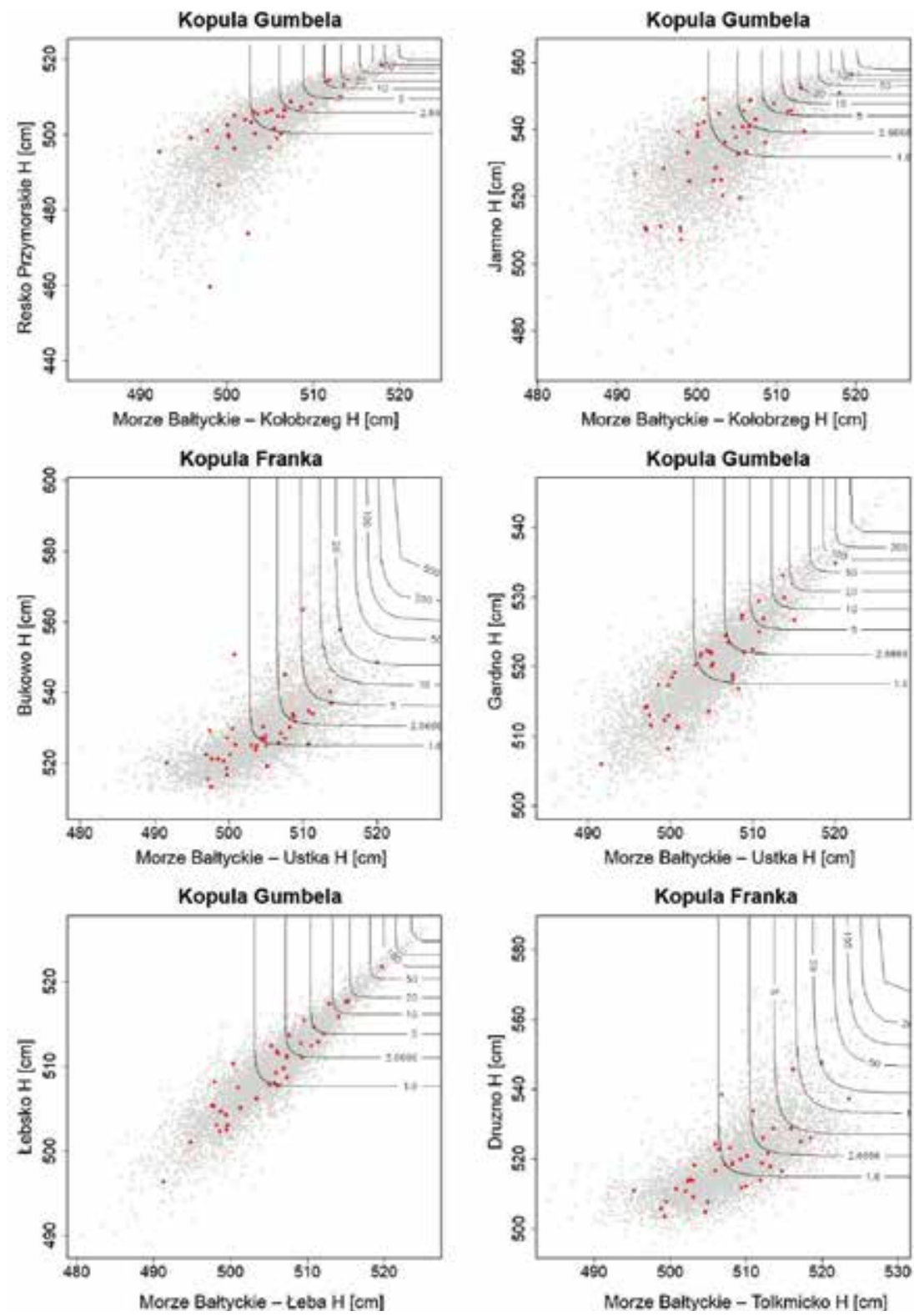

Ryc. 4. Łączne skumulowane krzywe prawdopodobieństwa przekroczeń stanów średnich rocznych dla zależności między stanami jezior a stanami Morza Bałtyckiego

Czerwone punkty - empiryczne pary wartości stanów średnich rocznych; szare punkty - punkty teoretyczne wygenerowane na podstawie obliczonych parametrów rozkładu łącznego.

Fig. 4. Total accumulated curves of probability of exceedance of mean annual water levels for the dependency between water levels of lakes and the Baltic Sea

Red points - empirical pairs of values of mean annual water levels; gray points - generated theoretical points based on calculated parameters of joint distribution. 
Tabela 7. Korelacje średnich miesięcznych stanów wody jezior przybrzeżnych i Morza Bałtyckiego w analizowanym wieloleciu

Table 7. Correlations of mean annual water levels of coastal lakes and the Baltic Sea in analyzed period

\begin{tabular}{ccccccc}
\hline Miesiąc & Resko Przymorskie & Jamno & Bukowo & Gardno & Łebsko & Druzno \\
\hline XI & 0,909 & 0,819 & 0,659 & 0,940 & 0,972 & 0,879 \\
XII & 0,888 & 0,530 & 0,625 & 0,894 & 0,927 & 0,837 \\
I & 0,767 & 0,754 & 0,754 & 0,972 & 0,940 & 0,837 \\
II & 0,896 & 0,767 & 0,793 & 0,951 & 0,964 & 0,819 \\
III & 0,956 & 0,777 & 0,791 & 0,928 & 0,926 & 0,841 \\
IV & 0,885 & $0,481^{* *}$ & 0,731 & 0,863 & 0,897 & 0,538 \\
V & 0,800 & 0,577 & 0,585 & 0,888 & 0,904 & 0,805 \\
VI & 0,725 & 0,679 & 0,723 & 0,926 & 0,907 & 0,743 \\
VII & 0,767 & 0,649 & 0,593 & 0,906 & 0,913 & 0,745 \\
VIII & 0,783 & 0,503 & 0,707 & 0,883 & 0,934 & 0,775 \\
IX & 0,697 & $0,387^{*}$ & 0,506 & 0,892 & 0,912 & 0,842 \\
X & 0,636 & 0,504 & 0,704 & 0,937 & 0,954 & 0,821 \\
\hline
\end{tabular}

Istotność statystyczna:* $\mathrm{p}<0,05, * * \mathrm{p}<0,01$, pozostałe współczynniki korelacji są istotne na poziomie $\mathrm{p}<0,001$.

Statistical significance: $* \mathrm{p}<0,05, * * \mathrm{p}<0.01$, other correlation coefficient are significant on the level $\mathrm{p}<0.001$.

nymi miesięcznymi stanami wody jezior i morza są wysokie i w zdecydowanej większości przypadków istotne statystycznie $(p<0,001)$. Najwyższe współczynniki korelacji między badanymi jeziorami i Morzem Bałtyckim $(>0,90)$ zanotowano w listopadzie, styczniu (Gardno, Łebsko) oraz w marcu (Resko Przymorskie, Łebsko) (Plewa i in. 2019). Jak zauważono, średnie stany wody jezior przybrzeżnych w większości wykazują większą synchroniczność ze stanami morza niż w przypadku analogicznej analizy dla zależności między stanami maksymalnymi rocznymi tych akwenów (Plewa i in. 2019). Może to oznaczać, że stany średnie morza $\mathrm{w}$ większym stopniu niż stany maksymalne wpływają na kształtowanie się stanów jezior przybrzeżnych. Potwierdzają to obliczone współczynniki korelacji, które również są wyższe dla analizy stanów średnich. Wyjątkiem od opisanej reguły jest Resko Przymorskie, którego stany maksymalne są i bardziej skorelowane, i wykazują wyższą synchroniczność ze stanami maksymalnymi Bałtyku (Plewa i in. 2019). Może być to spowodowane łatwiejszym dostępem wód morskich w momencie wezbrania do czaszy Reska niż w przypadku pozostałych jezior. 


\section{PODSUMOWANIE}

W pracy przedstawiono możliwość wykorzystania analizy synchroniczności do wyjaśniania zależności średnich rocznych stanów wody jezior przybrzeżnych od stanów morza. Zastosowana do tego celu metoda oparta na funkcjach kopul pokazuje, że nie tylko tradycyjne metody korelacji pozwalają na sprawdzenie związków i ich siły między ciągami pomiarowymi. Metody wykorzystujące funkcje kopul są coraz częściej używane w badaniach hydroklimatologicznych. Autorzy poparli wyniki synchroniczności tradycyjną metodą badania związków między danymi opisującymi środowisko przyrodnicze, czyli analizą współczynników korelacji. Zanotowano silny związek między wartościami współczynników korelacji a wynikami synchroniczności. Jednakże metoda oparta na kopulach wzbogaca informacje o współzależnościach między zmiennymi oraz rozszerza możliwości interpretacyjne, m.in. pozwalając obliczyć prawdopodobieństwo wystąpienia określonego stanu wody jeziora przy określonym stanie wody morza. Nie ograniczają jej także założenia, które często są istotnym mankamentem tradycyjnych metod, takie jak np. wymaganie, aby porównywane ciągi danych charakteryzowały się tym samym typem rozkładu statystycznego, $i$ to w dodatku rozkładem normalnym.

Na podstawie uzyskanych wyników wyciąga się wniosek o zróżnicowanej sile związków średnich rocznych stanów wody jezior przybrzeżnych w Polsce ze średnimi rocznymi stanami wody Morza Bałtyckiego. Wskazują na to zarówno wartości współczynników korelacji (wahające się od 0,67 dla jeziora Jamno do 0,91 dla jeziora Łebsko), jak i analiza synchroniczności (której wartości wahają się od 59,98\% do 77,54\%). Należy jednoznacznie potwierdzić, że takie związki istnieją, a ich siła jest średnia lub wysoka. Na siłę powiązań mogą mieć wpływ takie cechy jezior przybrzeżnych i ich zlewni, jak np. parametry kanału łączącego jezioro z morzem, powierzchnia zlewni jeziora czy zróżnicowane sumy opadów.

\section{LITERATURA}

Akaike H., 1974: A new look at the statistical model identification. IEEE Trans. Autom. Control, 19(6), 716-722.

Borowiak D., 2000: Reżimy wodne i funkcje hydrologiczne jezior Niżu Polskiego. Kat. Limnologii UG, Gdańsk.

Burandt P., Kobus S., Sidoruk M., Glińska-Lewczuk K., 2017: Hydrographic and hydrological characteristick part I: Liwia Łuża, Resko Przymorskie, Jamno, Kopań and Wicko. [w:] K. Obolewski, A. Astel, R. Kujawa, Hydroecological Determinants of Functioning of Southern Baltic Coastal Lakes. Wyd. Nauk. PWN, Warszawa.

Chlost I., Cieśliński R., 2005: Change of level of waters Laske Łebsko. Limnological Rev., 5, $17-26$.

Choiński A., 2006: Katalog jezior Polski. Wyd. Nauk. UAM, Poznań. 
Choiński A., 2007: Limnologia fizyczna Polski. Wyd. Nauk. UAM, Poznań.

Cieśliński R., 2010: Zróżnicowanie typologiczne i funkcjonalne jezior w polskiej strefie brzegowej poludniowego Bałtyku. Probl. Ekol. Krajobrazu, 26, 135-144.

Cieśliński R., 2016: Zmiany zasolenia i poziomu wody jeziora Jamno wynikające z budowy wrót przeciwsztormowych. Inż. i Ochr. Środ., 19, 517-539.

Cyberski J., Jędrasik J., 1992: Wymiana i cyrkulacja wód w jeziorze Gardno. [W:] K. Korzeniewski (red.), Zlewnia przymorskiej rzeki Łupawy i jej jeziora. WSP, Słupsk.

Czarnecka H. (red.), 2005: Atlas podziału hydrograficznego Polski. Zestawienia zlewni. IMGW, Warszawa.

Drwal J., Cieśliński R., 2007: Coastal lakes and marine intrusions on the southern Baltic coast. Oceanological and Hydrobiol. Stud., 36(2), 61-75.

Fac-Beneda J., 2013: Charakterystyka hydrologiczna jeziora Druzno. [W:] C. Nitecki, Monografia jeziora Druzno. Mantis, Olsztyn.

Girjatowicz J.P., 2001: Charakterystyki zlodzenia polskich jezior przybrzeżnych. Inż. Morska i Geotechn., 73-76.

Girjatowicz J.P., 2008a: Związek między poziomem wody w jeziorach przybrzeżnych $i$ wodami morskimi polskiego wybrzeża Morza Battyckiego. Przegl. Geofiz., 2, 141-153.

Girjatowicz J.P., 2008b: Miesięczne i sezonowe charakterystyki poziomów wody wybranych polskich jezior przybrzeżnych. Inż. Morska i Geotechn., 1, 27-32.

Girjatowicz J.P., 2011: Wpływ Morza Bałtyckiego na poziomy wód polskich jezior przybrzeżnych. Inż. Morska i Geotechn., 18-22.

Nelsen R.B., 1999: An Introduction to Copulas. Springer, New York, USA.

Paturej E., 2005: Zooplankton przymorskich jezior Pobrzeża Battyckiego. Wyd. Uniw. Warmińsko-Mazurskiego, Olsztyn.

Paturej E., 2006: Assessment of the trophic state of the coastal Lake Gardno based on community structure and zooplankton-related indices. Electron. Journ. of Pol. Agr. Univ., 9(2), 17.

Plewa K., 2018: Typy przebiegu pentadowych wspótczynników stanu wody jezior Niżu Polskiego. Bad. Fizjograf. Ser. A - Geogr. Fiz., A69, 161-177.

Plewa K., Perz A., Wrzesiński D., Sobkowiak L., 2019: Probabilistic Assessment of Correlations of Water Levels in Polish Coastal Lakes with Sea Water Level with the Application of Archimedean Copulas. Water, 11, 1292.

Salmi T., Määttä A., Anttila P., Ruoho-Airola T., Amnell T., 2002: Detecting Trends of Annual Values of Atmospheric Pollutants by the Mann-Kendall Test and Sen's Slope Estimates - The Excel Template Application MAKESENS. Publications on Air Quality 31; Finnish Meteor. Ins., Helsinki, Finlandia, 35.

Sklar A., 1959: Fonction de re' partition a 'n dimensions et leurs marges. Publications de L' Inst. de Statistique de l'Université de Paris, 8, 229-231.

Zhang J., Ding Z., You J., 2014: The joint probability distribution of runoff and sediment and its change characteristics with multi-time scales. Journ. Hydrol. Hydromech., 62, 218-225.

Zhao L., Xia, J., Sobkowiak L., Wang Z., Guo F., 2012: Spatial Pattern Characterization and Multivariate Hydrological Frequency Analysis of Extreme Precipitation in the Pearl River Basin, China. Water Resour. Management, 26, 3619-3637. 